World Lumen Congress 2021 | May 26-30, 2021 |

lasi, Romania

\title{
Teachers' Perception of the Phenomenon of Cyberbullying during the COVID-19 Pandemic
}

Elena-Ancuța ZĂVOIANU, Ion-Ovidiu PÂNIŞOARĂ https://doi.org/10.18662/wlc2021/74

How to cite: Zăvoianu, E.-A., \& Pânişoară, I.-O. (2021). Teachers' Perception of the Phenomenon of Cyberbullying during the COVID-19 Pandemic. In A. Sandu (vol. ed.), Lumen Proceedings: Vol. 17 World Lumen Congress 2021 (pp. 737-743). Iasi, Romania: LUMEN Publishing House. https://doi.org/10.18662/wlc2021/74 


\title{
Teachers' Perception of the Phenomenon of Cyberbullying during the COVID-19 Pandemic
}

\author{
Elena-Ancuța ZĂVOIANU11, Ion-Ovidiu PÂNIŞOARĂ²
}

\begin{abstract}
Cyberbullying is a negative social phenomenon that takes place online. It consists of harassing technology users through various means and various platforms. Frequent exposure to this phenomenon can cause emotional, mental and social problems for victims, witnesses and aggressors.

In the current pandemic context, when education has shifted to the online environment, and students spend a significant amount of time using different devices and online platforms, the number of cyberbullying cases is constantly increasing. There is currently little research describing how this phenomenon influenced online aggression.

In preventing and eliminating this phenomenon, teachers play an important role, due to the time they spend with students and the impact they can have on them.

In order to identify teachers' perceptions of this phenomenon during the pandemic and how they manage it in the classroom, we conducted a qualitative research on 10 teachers from primary and secondary schools. The results of the research were interesting and offered a new perspective on this phenomenon during Covid-19 crisis.
\end{abstract}

Keywords: Cyberbullying, students, teachers, perceptions, effects.

\section{Introduction}

Technology is a part of everyone's life, from young people to the elderly (Livingstone et al., 2011). Technology made life easier in terms of communication and working, but in the same time it made it quite dangerous for the mental health of the people who do not have basic digital literacy.

The rapid development of technology has led to the so-called cyberbullying phenomenon. Cyberbullying is a type of online harassment that uses technology and internet in order to produce harm (Smith et al., 2008). This phenomenon involves the intentional provocation of the victim's suffering by sending malicious messages, sharing photos that lead to denigration of the victim, creating fake profiles, exclusion from groups, blackmail and threats.

\footnotetext{
${ }^{1} \mathrm{PhD}$ student, Faculty of Psychology and Educational Studies, University of Bucharest, Romania: elena.zavoianu@drd.unibuc.ro

2 Professor, Faculty of Psychology and Educational Studies, University of Bucharest, Romania: ovidiu.panisoara@fpse.unibuc.ro
} 
Cyberbullying is considered to be an extension of bullying in the online world. The two phenomena have similar characteristics such as: intentionality, frequency and unequal power relations (Tokunaga, 2010). What distinguishes them is the place where this phenomenon takes place, respectively at school and at home (Vaillancourt et al., 2017).

Cyberbullying is an extremely dangerous phenomenon, because unlike the victim of bullying, the victim of this contemporary phenomenon can be assaulted anytime, anywhere and by anyone with an internet connection. Especially today, when most courses take place online due to Covid-19.

Regarding the causes that trigger this behavior among the aggressors, they can be multiple, and Luwing (2010) supported the idea that all children can be aggressors at some point. Among the best known are: the need for attention, the desire to have power (Whitson, 2017), social difficulties in establishing relationships, family problems, the desire to improve one's social status (Faris \& Felmee, 2011) etc.

One factor that increased the number of cases of cyberbullying is the possibility of the aggressor to remain anonymous. This possibility and the fact that the aggressors are not punished for their deeds, makes them unaware of the negative effects that their behavior produces among the victims and witnesses (Malamut et al., 2020).

The effects of this phenomenon influence the personality of the victim until adulthood, in case of non-specialized intervention. The best known effects are: eating disorders, anxiety, depression, sleep disorders, irritability, absenteeism, somatizations, decrease of self-confidence, isolation, decrease of school performance, substance abuse and in some more serious cases suicide (Tanrikulu, 2018).

According to Aboujaoude et al. (2015) and Patchin and Hinduja (2019), the number of cyberbullying cases have doubled from 2007 to 2019 , from $18 \%$ to $37 \%$, and continues to grow this year as all activities have moved online because of Covid-19, and some students and teachers did not have the necessary skills to continue the educational process online (Papagiannidis et al., 2020). Teachers and parents need to be aware that this shift from the classroom to the online environment exposes children to cyber threats (Dwivedi et al., 2020).

In mediating online and offline conflicts, teachers play an important role between students (Popović-Ćitić et al., 2011), and in the context of COVID-19 this happens more than ever. They spend a significant amount of time with students, are role models for them and can teach them how to feel safe on the internet by introducing a series of prevention and intervention strategies during online classes (Biggs et al., 2008). Teachers' discussions with students about the rules in the online environment can lead to the prevention of aggression and the creation of a positive school climate.

Unfortunately, not all teachers have the necessary skills to intervene effectively in cases of cyberbullying, which also leads to a decrease in the quality of prevention programs implemented in school (Sakellariou et al., 2012). Macaulay et al. (2018) argues that the approach to cyber aggression is inconsistent due to the fact that teachers do not trust their ability to identify and manage these cases, 
supporting the need for additional training in this area.

Currently, few studies have focused on identifying teachers' perceptions of this phenomenon, even though their knowledge provides important information for school policy development that can prevent and reduce cyberbullying cases.

\section{Methods and procedure}

In order to identify how the teacher manages this phenomenon during the online classes, we conducted interviews with 10 teachers from the primary and secondary school from urban area.

The objectives of the interview were: identifying the level of training of teachers in conducting online classes, identifying how teachers handle this phenomenon, identifying changes in student behavior in the online environment and identifying similarities and differences between how teachers manage bullying and cyberbullying.

The interview was semi-structured and focused on four components: identification data, online classes, management of cyberbullying, student behaviors in the context of online lessons.

The subjects' answers were recorded and then transcribed and analyzed. Subjects were assured of anonymity and confidentiality. The interviews lasted about 60 minutes and were conducted physically, because we did not want to lose sight of the nonverbal components of communication. The subjects' answers were analyzed and coded and classified into various categories.

\section{Participants}

The teachers were chosen at random from 10 schools in urban areas, 5 teachers in primary school and 5 teachers in secondary school, with teaching experience between 5 and 30 years. All the teachers were female and stated that they like this profession, despite the fact that they face daily challenges.

\section{Results}

Regarding the conduct of online classes, during the Covid-19 pandemic, teachers said that it was quite difficult for them to adjust to online teaching. They were all familiar with the technology and used it in class, but it was not an integral part of the lesson.

"Although I can call myself a digital native, I found it most difficult to keep students engaged with the help of technology. I feel like I have no control over them. When I share the screen with them, I don't know who is following me and who isn't, what is their contribution and what is the contribution of their parents and the Google search engine in solving their work tasks. "

A large part of the interviewed teachers do not know how to keep the students motivated throughout an hour of class. Also, other answers were about 
how the online class should be conducted, if the class should be limited to explanations, only writing or both. Some teachers have reported that online classes are shorter than physical ones and prevent them from organizing their lesson as they wish. Another problem reported by teachers was the fact that when they share the screen with students, they fail to monitor them.

Online classes have led to the creation of a new type of cyberbullying, one that has threatened the safety of students and teachers during classes. According to teachers, these actions may also explain the refusal of some students to turn on the camcorder during class.

"There were cases in which various students distributed the links to access online courses to friends who came in and disturbed the class, played music, swore and sent annoying chat messages. It was very stressful and difficult to manage these situations, especially until we found a platform to prevent the participation of people from the outside. There were cases in which the respective students or the aggressors created false accounts with the names of their colleagues and distributed inappropriate images or offensive messages."

8 out of 10 teachers said that they discussed about this phenomenon only when they have faced it in class. Most teachers used different ways to manage the cases presented above, such as: discussions on the consequences of this phenomenon, identification and prevention, meetings with parents and inviting a police officer to talk about cyber security.

"I remember that when I heard that such online conflicts were taking place between the students in the class, I talked to them a lot during the leadership class, I came up with interesting presentations and I even called a policeman to talk to them."

Most teachers talked to the victims, the aggressors and their parents, and in the worst cases they took measures regarding the grade. Primary school teachers did not have examples of cases in the classroom. The number of subjects interviewed is small enough to conclude that cases of cyberbullying are lower in primary education.

According to teachers, the most exposed gender to become a victim of cyberbullying is female. Teachers afirmed that the networks through which the victims are assaulted are the messenger of Facebook, Whatsapp, Instagram and the creation of memes with the victims and even embarrassing content on the Tik Tok platform.

Regarding the behavior of students during online classes, both primary and secondary school teachers said that they face a decrease in students' motivation for learning, difficulties of concentration and even excessive shyness. Thus, students who were eager to assert themselves, suddenly became de-motivated, do not turn on their cameras and invoke technical or connection problems.

"It seems to me that good students have suddenly become calmer, and those who usually create problems and disturb the class have invented new ways of doing this. Thus, they write over the shared screen, show various signs or objects in front of the camera to get the attention of colleagues, make different sounds or put different sounds when I share the screen and I don't have them all in front of me."

Primary and secondary school students have developed a virtual identity. Teachers notice changes in students' personalities. They can be determined either by 
the desire to attract attention, or by the fear of being registered or by the presence of parents.

\section{Conclusions}

The online school conducted during the COVID-19 pandemic has encouraged an increase in the number of victims of cyberbullying. According to the research conducted, teachers became more aware of this phenomenon and discovered that physical aggression at school has moved to the online environment, taking a much more aggressive form, which has devastating effects for the victim.

Online classes have led students to develop a virtual personality that help them stay safe and eliminate the risk of becoming characters in memes or on Tik Tok platforms. The aggressors' ability to remain anonymous has led many students to disrupt teachers' classes, send them offensive messages, e-mails, or transform colleagues into victims. The introduction of school policies regarding the registration of courses and the identification of secure platforms for conducting online courses have given more security to students and teachers.

This study concluded that the methods of intervention and prevention imposed by teachers are quite limited and ineffective for the current context. Discussions with students and parents and even lowering the aggressor's grades are considered ineffective measures by teachers. They support the development of digital literacy workshops for both parents and students to ensure continuing education in this field.

In conclusion, cyberbullying is a consequence of the use of technology. It is quite difficult to eliminate it, and the cheapest way to treat it is to prevent it. This must be done by both parents and teachers. Discussions about this phenomenon, the presentation of examples of famous cases, learning ways to cope and holding workshops on socio-emotional development for students play a key role in reducing cases of cyberbullying.

\section{Limitations of the research}

The limits of this research are represented by: the lack of a large number of subjects, the subjectivity in processing and coding the answers and the lack of sincerity of some respondents.

\section{References}

Aboujaoude, E., Savage, M. W., Starcevic, V., \& Salame, W. O. (2015). Cyberbullying: Review of an old problem gone viral. Journal of Adolescent Health, 57(1), 10-18. https://doi.org/10.1016/j.jadohealth.2015.04.011

Athanasiou, K., Melegkovits, E., Andrie, E. K., Magoulas, C., Tzavara, C. K., Richardson, C., Greydanus, D., Tsolia, M., \& Tsitsika, A. K. (2018). Cross-national aspects of cyberbullying victimization among 14-17-year-old adolescents across seven 
European countries. BMC Public Health, 18(1), 800. https://doi.org/10.1186/s12889-018-5682-4

Biggs, B. K., Vernberg, E. M., Twemlow, S. W., Fonagy, P., \& Dill, E. J. (2008). Teacher adherence and its relation to teacher attitudes and student outcomes in an elementary school-based violence prevention program. School Psychology Review, 37(4), 533-549. http://dx.doi.org/10.1080/02796015.2008.12087866

Dwivedi, Y. K., Hughes, D. L., Coombs, C., Constantiou, I., Duan, Y., Edwards, J. S., Gupta, B., Lal, B.., Misra, S., Prashant, P., Raman, R., Rana, N. P., Sharma, S. K., \& Upadhyay, N. (2020). Impact of COVID-19 pandemic on information management research and practice: Transforming education, work and life. International Journal of Information Management, 55, 102211. http://dx.doi.org/10.1016/i.ijinfomgt.2020.102211

Faris, R., \& Felmlee, D. (2011). Status struggles: Network centrality and gender segregation in same- and cross-gender aggression. American Sociological Review, 76(1), 48-73. https://doi.org/10.1177/0003122410396196

Grădinaru, C., \& Stoica, T. (2018). Studiu privind utilizarea Internetului de către copii [Study about the use of the Internet among children]. https://www.salvaticopiii.ro/sciro/files/92/928f0bff-bffa-447a-9a27-df979ba1008f.pdf

Hinduja, S., \& Patchin, J. W. (2019). Cyberbullying identification, prevention, and response. https://cyberbullying.org/Cyberbullying-Identification-Prevention-Response2019.pdf

Livingstone, S., Haddon, L., Gorzig, A., \& Olafsson, K. (2011). Risks and safety on the internet: the perspective of European children: full findings and policy implications from the EU Kids Online survey of 9-16 year olds and their parents in 25 countries. EU Kids Online Network. http://eprints.lse.ac.uk/33731/1/Risks $\% 20$ and $\% 20$ safety $\% 20$ on $\% 20$ the $\% 20$ intern et $\% 281$ sero $\% 29 . p d f$

Luwing, T. (2010). Confessions of a former bully. Random House.

Macaulay, P. J., Betts, L. R., Stiller, J., \& Kellezi, B. (2018). Perceptions and responses towards cyberbullying: A systematic review of teachers in the education system. Aggression and Violent Behavior, 43, 1-12. http://doi.org/10.1016/j.avb.2018.08.004

Malamut, S. T., van den Berg, Y. H. M., Lansu, T. A. M., \& Cillessen, A. H. N. (2020). Dyadic nominations of bullying: Comparing types of bullies and their victims. Aggressive Behavior, 46(3), 232-243. https://psycnet.apa.org/doi/10.1002/ab.21884

Papagiannidis, S., Harris, J., \& Morton, D. (2020). WHO led the digital transformation of your company? A reflection of IT related challenges during the pandemic. International journal of information management, 55, 102166. https://dx.doi.org/10.1016\%2Fj.ijinfomgt.2020.102166

Popović-Ćitić, B., Djurić, S., \& Cvetković, V. (2011). The prevalence of cyberbullying among adolescents: A case study of middle schools in Serbia. School Psychology International, 32(4), 412-424. https://doi.org/10.1177\%2F0143034311401700

Sakellariou, T., Carroll, A., \& Houghton, S. (2012). Rates of cyber victimization and bullying among male Australian primary and high school students. School Psychology International, 33(5), 533-549. http://dx.doi.org/10.1177/0143034311430374

Smith, K., Mahdavi, J., Carvalho, M., Fisher, S., Russell, S., \& Tippett, N. (2008). Cyberbullying: its nature and impact in secondary school pupils. The Journal of Child 
Elena-Ancuţa ZĂVOIANU et al.| Lumen Proceedings 17 | WLC 2021

Psychology and Psychiatry, 49(4), 376-385. https://doi.org/10.1111/j.14697610.2007.01846.x

Tanrikulu, I. (2018). Cyberbullying prevention and intervention programs in schools: A systematic review. School Psychology International, 39(1), 74-91. https://doi.org/10.1177\%2F0143034317745721

Tokunaga, R., S. (2010). Following you home from school: A critical review and synthesis of research on cyberbullying. Computers in Human Behavior, 26(3), 277-287. https://doi.org/10.1016/j.chb.2009.11.014

Vaillancourt, T., Faris, R., Mishna, F. (2017). Cyberbullying in children and youth: implications for health and clinical practice. The Canadian Journal of Psychiatry, 62(6), 368-373. https://doi.org/10.1177/0706743716684791

Whitson, S. (2014). 8 Keys to end bullying: Strategies for parents \& schools. W. Norton \& Company. 